\title{
KOMPETENSI SDM DAN BUDAYA ORGANISASI DAMPAKNYA TERHADAP KEUNGGULAN KOMPETITIF
}

\section{COMPETENCE OF HR AND ORGANIZATIONAL CULTURE OF THE IMPACT ON COMPETITIVE ADVANTAGE}

\author{
M. Naely Azhad, Seno Sumowo, Anwar, Nurul Qomariah \\ Fakultas Ekonomi Universitas Muhamamdiyah Jember \\ Email: naelyazhad@unmuhjember.ac.id, seno.sumowo@unmuhjember.ac.id, \\ anwar@unmuhjember.ac.id; nurulqomariah@unmuhjember.ac.id (correspondence \\ author)
}

\begin{abstract}
ABSTRAK
Peningkatan mutu makanan yang dihasilkan UMKM yang ada di Jawa Timur mendesak untuk segera dilakukan. Peningkatan mutu makanan ini terkait erat dengan keunggulan bersaing UMKM. Jika mutu makanan yang dihasilkan UMKM baik maka keunggulan bersaing UMKM akan meningkat. Keunggulan bersaing merupakan salah satu faktor yang mempengaruhi keberlanjutan suatu organisasi. UMKM merupakan salah satu organisasi yang memiliki tingkat persaingan yang sangat tinggi karena sektor makanan ini merupakan sektor yang mempunyai banyak peminat. Tujuan penelitian ini adalah untuk mengetahui dampak kompetensi SDM dan penerapan budaya organisasi terhadap keunggulan bersaing pada UMKM pangan yang ada di Jawa Timur. Populasi penelitian adalah seluruh pimpinan UMKM yang ada di Jawa Timur yang meliputi 6 kabupaten. Adapun Kabupaten yang menjadi obyek penelitian adalah Kabupaten Jember, Bondowoso, Situbondo, Banyuwangi dan Kabupaten Lumajang dengan jumlah UMKM sebanyak 85.500. Pengambilan sampel dilakukan dengan menggunakan metode Stratified Random Sampling untuk setiap kabupaten yang ada. Sampel penelitian ditentukan dengan menggunakan rumus Slovin dan diperoleh sebanyak 133 UMKM yang menjadi responden. Hasil penelitian menunjukkan bahwa kompetensi SDM mempunyai pengaruh yang signifikan terhadap keunggulan bersaing UMKM Makanan di Jawa Timur dan budaya organisasi mempunyai pengaruh yang signifikan terhadap keunggulan bersaing UMKM Makanan di Jawa Timur.

Kata Kunci: keunggulan kompetitif, kompetensi sumber daya manusia, budaya organisasi, UMKM, kinerja
\end{abstract}

\begin{abstract}
Improving the quality of food produced by MSMEs in East Java is urgent. This food quality improvement is closely related to the competitive advantage of MSMEs. If the quality of food produced by MSMEs is good, the competitive advantage of MSMEs will increase. Competitive advantage is one of the factors that influence the sustainability of an organization. MSMEs are one organization that has a very high level of competition because the food sector is a sector that has many interested parties. The purpose of this study was to determine the impact of HR competencies and the application of organizational culture to competitive advantage in food MSMEs in East Java.
\end{abstract}


The study population was all UMKM leaders in East Java which included 6 districts. The regencies that were the object of research were Jember, Bondowoso, Situbondo, Banyuwangi and Lumajang Regencies with a total of 85,500 MSMEs. Sampling was carried out using the Stratified Random Sampling method for each district. The research sample was determined using the Slovin formula and obtained as many as 133 MSMEs who were respondents. The results showed that HR competencies had a significant effect on the competitive advantage of MSMEs in East Java and the organizational culture had a significant influence on the competitive advantage of Food SMEs in East Java.

Keywords: competitive advantage, competency in human resources, organizational culture, MSMEs, performance

\section{PENDAHULUAN}

UMKM merupakan andalan bagi pemerintah dalam meningkatkan pertumbuhan ekonomi secara nasional. Ketika terjadi krisis ekonomi yang menimpa Indonesia pada tahun 1997, ternyata UMKM mampu bertahan dan menjadi tumpuhan perekonomian Indonesia. Krisis ini ternyata memotivasi pertumbuhan sektor usaha kecil yang semakin hari semakin menyerap tenaga kerja dan semakin memperkuat inovasi pengembangan usaha kecil. Hal tersebut dapat dilihat melalui perkembangan UMKM sepanjang tahun 2011 terbukti mampu berkontribusi dalam pembentukan PDB sebesar 57,60\%. Perinciannya sebagai berikut, sebanyak 32,02\% oleh Usaha Mikro, sejumlah 10,99\% oleh Usaha Kecil, dan sejumlah 14,59\% oleh Usaha Menengah. Nilai rata-rata pembentukan PDB oleh UMKM Rp 24,8 juta per unit usaha. UMKM mampu merekrut tenaga kerja baru sebanyak 2,32 juta orang, atau setara dengan 97,8\% dari lapangan kerja baru yang diciptakan UMKM dan usaha besar di tahun 2011. Penyerapan tenaga kerja baru banyak dilakukan oleh Usaha Mikro, jumlahnya 1,94 juta orang, termasuk mempekerjakan dirinya sendiri. Usaha Kecil mampu menyerap tenaga kerja baru sebanyak 292.000 orang ( Biarto dan Ardianti, 2013).

Sektor Usaha Mikro Kecil dan Menengah (UMKM) merupakan kunci pertumbuhan perekonomian di Jawa Timur. Hal ini dibuktikan dengan kontribusi UMKM terhadap Produk Domestik Regional Bruto (PDRB) mencapai 54,98\% atau sebesar Rp. 1.1689,88 triliun. Jumlah itu sekitar 50 persen lebih banyak ketimbang jumlah UMKM berdasarkan survey hingga tahun 2006 yang juga dilakukan BPS Jatim, yang mencapai angka 4,2 juta UMKM. Fakta tersebut mengemukan dalam seminar hasil survey UMKM Provinsi Jawa Timur tahun 2012 yang digelar di kantor Badan Perencanaan 
Pembangunan Daerah (Bappeda) Provinsi Jatim di Surabaya pada tahun 2013. Hingga akhir 2012 jumlah UMKM di Jatim mencapai 6.825.931 usaha. (Bappeda Jatim, 2013). Komposisi dari UMKM antara lain yang bergerak di sektor pertanian sebesar 60,25 persen dengan jumlah unit usaha sebanyak 4.112.443 usaha, dan sektor non pertanian sebesar 39,75 persen dengan jumlah unit usaha sebanyak 2.713.488 usaha. Berdasarkan jumlah UMKM di masing-masing kabupaten dan kota, jumlah terbesar ada di Kabupaten Jember yakni sebanyak 424.151 usaha. Setelah Jember, jumlah UMKM terbanyak selanjutnya ada di Kabupaten Malang dan Kabupaten Banyuwangi. Masing-masing memberi kontribusi 6,07 persen dan 4,35 persen terhadap keseluruhan jumlah UMKM. Permasalahan yang dihadapi UMKM pangan yang ada di Jawa Timur adalah dari sekitar 6 juta UMKM di Jatim, yang memiliki sertifikasi halal hanya sekitar 15\%. Kondisi tersebut terjadi karena biaya sertifikasi halal masih mahal dan pengusaha kecil belum mampu melakukannya. Padahal pasar di Indonesia sekarang ini sudah lebih sadar terhadap produk halal, untuk itu produk kita harus sudah disertifikasi halal agar tidak dikalahkan dengan produk asing, bahkan dengan mensertifikasi halal akan bisa memperluas pasar ekspor terutama di negara-negara Islam seperti Timur Tengah. Oleh karena itu sebagai unit usaha mikro yang berperan dalam meningkatkan perekonomian Indonesia, maka UMKM sector pangan dituntut untuk terus meningkatkan kinerjanya. Peningkatan persaingan yang semakin tajam memaksa organisasi baik itu perusahaan besar dan perusahaan kecil seperti UMKM untuk memusatkan perhatian pada peningkatan keunggulan bersaing, kompetensi sumber daya manusia dan budaya organisasi.

Untuk itu persoalan ini segera dipecahkan, salah satunya dengan membangun model peningkatan keunggulan bersaing UMKM sebagai upaya untuk meningkatkan kinerja organisasi UMKM bidang makanan yang ada di Jawa Timur yang berbasis kompetensi SDM dan budaya organisasi. Model ini mempunyai keunggulan dalam peningkatan keunggulan bersaing UMKM yang bergerak dibidang pengolahan makanan, dan dapat mengurangi konflik horisontal di masyarakat terkait dengan sertifikasi produk halal makanan yang dihasilkan oleh UMKM. Tujuan dari penelitian ini adalah meningkatkan keunggulan UMKM bidang pengolahan makanan yang ada di Jawa Timur yang berbasis kompetensi sumberdaya dan budaya organisasi. 


\section{TINJAUAN PUSTAKA}

\section{Keunggulan Bersaing}

Konsep keunggulan bersaing organisasi banyak dikembangkan dari strategi generik. Menurut Dirgantoro (2001:159) bahwa, "keunggulan bersaing merupakan perkembangan dari nilai yang mampu diciptakan perusahaan untuk pembelinya". Hal-hal yang dapat mengindikasikan variabel keunggulan bersaing adalah imitabilitas, durabilitas, dan kemudahan menyamai. Keunggulan organisasi. Keunggulan bersaing dapat dipahami dengan memandang organisasi sebagai keseluruhan, berasal dari banyak aktivitas yang berlainan yang dilakukan oleh organisasi dalam mendesain, memproduksi, memasarkan, menyerahkan dan mendukung penjualan. Sehingga keunggulan bersaing adalah suatu posisi yang masih dikerjakan organisasi sebagai upaya mengalahkan pesaing (Porter, 1993).

\section{Kompetensi Sumberdaya Manusia}

Teori berbasis sumberdaya menyatakan bahwa organisasi dapat menciptakan dan mempertahankan keunggulan kompetitifnya melalui proses penciptaan nilai yang langka dan sulit ditiru para kompetitor (Malayu, 2007). Indikasinya dapat dinilai dari kemampuan organisasi untuk mengkreasikan kebijakan dan praktik-praktik MSDM yang unik dan sulit ditiru pesaing. Hal ini akan mendorong terjadinya interaksi antar individu yang menghasilkan pengetahuan dan modal sosial serta menjadi pembeda organisasi atau perusahaan dengan pesaingnya yang kemudian mampu memberikan keuntungan ekonomis positif serta tidak mudah ditiru (Mathis dan Jackson, 2002).

\section{Budaya Organisasi}

Pabundu (2006) mengemukakan bahwa budaya organisasi merupakan sebuah sistem makna bersama yang dianut oleh para anggota yang membedakan suatu organisasi dari organisasi-organisasi lainnya. Budaya organisasi adalah sebuah pola asumsi dasar yang diciptakan, ditemukan atau dikembangkan oleh suatu kelompok tertentu sebagai landasan dalam berperilaku dalam organisasi. Dimana akan diturunkan kepada anggota baru sebagai cara bagaimana melihat, berpikir, dan merasa dalam organisasi. Tingginya tingkat persaingan antar organisasi membuat para pengambil keputusan perlu melakukan kajian yang mendalam tentang budaya organisasi atas 4 (empat) elemen yang saling berkaitan yaitu faktor manajerial, faktor lingkungan, kultur organisasi, perencanaan stratejik dan keunggulan bersaing. Budaya organisasi mencakup mengenai nilai, aturan, kepercayaan di dalamnya yang membentuk perilaku, sikap yang menguntungkan. 


\section{Kinerja Organisasi}

Kinerja sudah menjadi kata popular yang sangat menarik dalam pembicaraan manajemen publik. Konsep kinerja pada dasarnya dapat dilihat dari dua segi, yaitu kinerja pegawai dan kinerja organisasi. Kinerja adalah gambaran mengenai tingkat pencapaian pelaksanaan tugas dalam suatu organisasi, dalam upaya mewujudkan sasaran, tujuan, misi, dan visi organisasi tersebut. Kinerja organisasi adalah totalitas hasil kerja yang dicapai suatu organisasi tercapainya tujuan organisasi berarti bahwa, kinerja suatu organisasi itu dapat dilihat dari tingkatan sejauh mana organisasi dapat mencapai tujuan yang didasarkan pada tujuan yang sudah ditetapkan sebelumnya (Malayu, 2007).

\section{METODE PENELITIAN}

Rancangan penelitian yang dilakukan pada penelitian ini adalah penelitian survei karena pada umumnya yang merupakan unit analisis pada suatu penelitian survei adalah individu. Dalam penelitian survei, informasi yang dibutuhkan dikumpulkan dari responden dengan menggunakan kuisioner (Ghozali, 2006). Dalam penelitian ini menggunakan sampel sebanyak 133 UMKM dari 85.500 UMKM yang ada di Jawa Timur dengan rincian setiap kabupaten dilakukan pengambilan sampel dengan menggunakan teknik pengambilan sampelnya adalah stratified random sampling.

Penelitian ini merupakan penelitian yang bersifat diskriptif analitis yaitu menggambarkan karakteristik responden dan untuk menguji variabel penelitian yang ada, dengan pendekatan kuantitatif (Ghozali, 2006). Variabel-variabel yang akan dianalisis dalam penelitian ini adalah variabel : Keunggulan bersaing, kompetensi SDM dan budaya organisasi UMKM.

Penelitian ini menggunakan teknik analisis data kualitatif dengan prosedur reduksi data, penyajian data, penarikan kesimpulan atau verifikasi. Penyajian sebuah diagram path untuk mempermudah melihat hubungan kausalitas yang akan diuji. Melalui diagram path ditunjukkan hubungan kausalitas antara variabel endogen dan variabel eksogen, sehingga dapat diestimasi melalui program Amos. 


\section{HASIL DAN PEMBAHASAN}

\section{Hasil Penelitian}

Analisis deskriptif dilakukan dengan mengamati kecenderungan-kecenderungan dan penyimpangan data setiap variabel penelitian melalui modus indikator-indikatornya masing-masing. Hasil analisis statistik deskriptif dapat dilihat dalam tabel berikut.

Tabel 1. Analisis Deskriptif Skor Jawaban Responden

\begin{tabular}{|c|c|c|c|c|}
\hline No. & Variabel & Indikator & Modus & Kategori Variabel \\
\hline \multirow{7}{*}{1} & \multirow{7}{*}{$\begin{array}{l}\text { Kompetensi SDM } \\
\left(\mathrm{X}_{1}\right)\end{array}$} & X11 & 4 & \multirow{7}{*}{ Baik } \\
\hline & & $\mathrm{X} 12$ & 4 & \\
\hline & & $\mathrm{X} 13$ & 4 & \\
\hline & & X14 & 4 & \\
\hline & & $\mathrm{X} 15$ & 4 & \\
\hline & & $\mathrm{X} 16$ & 4 & \\
\hline & & $\mathrm{X} 17$ & 4 & \\
\hline \multirow{7}{*}{2} & \multirow{7}{*}{$\begin{array}{l}\text { Budaya Organisasi } \\
\left(\mathrm{X}_{2}\right)\end{array}$} & $\mathrm{X} 21$ & 5 & \multirow{7}{*}{ Baik } \\
\hline & & $\mathrm{X} 22$ & 4 & \\
\hline & & $\mathrm{X} 23$ & 5 & \\
\hline & & $\mathrm{X} 24$ & 5 & \\
\hline & & $\mathrm{X} 25$ & 4 & \\
\hline & & $\mathrm{X} 26$ & 4 & \\
\hline & & $\mathrm{X} 27$ & 4 & \\
\hline \multirow{7}{*}{3} & \multirow{7}{*}{$\begin{array}{l}\text { Keunggulan } \\
\text { Bersaing (Z) }\end{array}$} & $\mathrm{Z1}$ & 4 & \multirow{7}{*}{ Baik } \\
\hline & & $\mathrm{Z} 2$ & 4 & \\
\hline & & $\mathrm{Z3}$ & 4 & \\
\hline & & $\mathrm{Z4}$ & 4 & \\
\hline & & $\mathrm{Z} 5$ & 5 & \\
\hline & & Z6 & 4 & \\
\hline & & $\mathrm{Z7}$ & 4 & \\
\hline
\end{tabular}

Sumber: Data Diolah 2018.

Berdasarkan tabel 1 dapat diketahui bahwa variabel kompetensi SDM ( $\left.\mathrm{X}_{1}\right)$ memiliki nilai modus secara keseluruhan $=4$. Hal ini berarti variabel kompetensi SDM dipersepsikan baik oleh pimpinan UMKM makanan di Jawa Timur yang ditunjukkan melalui pimpinan UMKM menjalin hubungan baik dengan semua stakeholders (karyawan, pemasok, dan pemerintah) agar meningkatkan kinerja usaha, pimpinan UMKM memahami pentingnya penguasaan pengetahuan berkaitan dengan usaha yang dijalankan, pimpinan UMKM selalu memperhatikan dan terus mendorong peningkatan kemampuan karyawan, pimpinan UMKM terus berusaha menguasai kompetensi tentang riset pasar dan strategi pengembangan usaha, merasa perlu menguasai kompetensi 
bidang keuangan untuk menunjang usaha, pimpinan UMKM senantiasa berusaha meningkatkan kompetensi tentang pengembangan produk dan usaha, dan pimpinan UMKM meyakini bahwa komitmen terhadap waktu kerja dapat menunjang keberhasilan usaha.

Variabel budaya organisasi $\left(\mathrm{X}_{2}\right)$ memiliki nilai modus secara keseluruhan $=4$. Hal ini berarti variabel budaya organisasi dipersepsikan baik oleh pimpinan UMKM makanan di Jawa Timur yang ditunjukkan melalui selalu menciptakan ide-ide yang inovatif dalam pekerjaan, selalu memperhatikan segala ketetapan, analisis, dan memperhatikan lebih detail terhadap hal-hal di sekitar pekerjaan, selalu fokus kepada hasil kerja daripada teknik dan proses yang digunakan, memperhitungkan pengaruh hasilhasil terhadap karyawan dalam organisasi, memiliki kemampuan bekerjasama dalam tim, sebagai anggota organisasi selalu tertantang untuk bekerja dengan kompetitif, dan sebagai anggota organisasi selalu dituntut untuk terus tumbuh dan berkembang.

Variabel keunggulan bersaing $(Z)$ memiliki nilai modus secara keseluruhan $=4$. Hal ini berarti variabel keunggulan bersaing dipersepsikan baik oleh pimpinan UMKM makanan Di Jawa Timur yang ditunjukkan melalui harga produk yang lebih murah dari pesaing akan meningkatkan keunggulan bersaing, produk mempunyai ciri khas khusus yang susah untuk ditiru pesaing, penggunaan teknologi modern dapat meningkatkan keunggulan bersaing, perusahaan dan karyawan bekerjasasama dengan baik dan bertanggungjawab, perusahaan peka terhadap perubahan permintaan konsumen, perusahaan menawarkan produk yang berkualitas tinggi daripada pesaingnya, dan perusahaan bergerak cepat dalam mengembangkan produk baru dibanding dengan pesaing.

\section{Uji Validitas dan Realibilitas}

Validitas instrumen menunjukkan bahwa suatu alat ukur mampu mengungkapkan data dengan tepat dan memberikan gambaran yang cermat mengenai data tersebut. Kesahihan suatu data apabila faktor loading dari indicator variabel memiliki nilai diatas 0,50, maka dapat dikatakan bahwa item pertanyaan sebagai penyusun unobserved variable dalam path analysis adalah valid (Ghozali, 2005). Hasil uji validitas secara ringkas dapat dilihat pada tabel 2. 
Tabel 2. Hasil Uji Validitas

\begin{tabular}{|c|c|c|c|c|}
\hline No. & Variabel & Indikator & Estimate & Keterangan \\
\hline \multirow{7}{*}{1} & \multirow{7}{*}{ Kompetensi SDM $\left(\mathrm{X}_{1}\right)$} & $\mathrm{X} 11$ & 0,864 & Valid \\
\hline & & $\mathrm{X} 12$ & 0,865 & Valid \\
\hline & & $\mathrm{X} 13$ & 0,921 & Valid \\
\hline & & X14 & 0,654 & Valid \\
\hline & & $\mathrm{X} 15$ & 0,525 & Valid \\
\hline & & $\mathrm{X} 16$ & 0,584 & Valid \\
\hline & & $\mathrm{X} 17$ & 0,681 & Valid \\
\hline \multirow{7}{*}{2} & \multirow{7}{*}{ Budaya Organisasi $\left(\mathrm{X}_{2}\right)$} & $\mathrm{X} 21$ & 0,535 & Valid \\
\hline & & $\mathrm{X} 22$ & 0,675 & Valid \\
\hline & & $\mathrm{X} 23$ & 0,789 & Valid \\
\hline & & $\mathrm{X} 24$ & 0,780 & Valid \\
\hline & & $\mathrm{X} 25$ & 0,732 & Valid \\
\hline & & $\mathrm{X} 26$ & 0,799 & Valid \\
\hline & & $\mathrm{X} 27$ & 0,528 & Valid \\
\hline \multirow{7}{*}{3} & \multirow{7}{*}{$\begin{array}{l}\text { Keunggulan } \\
(\mathrm{Z})\end{array}$} & $\mathrm{Z1}$ & 0,654 & Valid \\
\hline & & $\mathrm{Z} 2$ & 0,602 & Valid \\
\hline & & $\mathrm{Z3}$ & 0,578 & Valid \\
\hline & & $\mathrm{Z} 4$ & 0,583 & Valid \\
\hline & & $\mathrm{Z} 5$ & 0,679 & Valid \\
\hline & & Z6 & 0,696 & Valid \\
\hline & & $\mathrm{Z7}$ & 0,539 & Valid \\
\hline
\end{tabular}

Sumber : Data Diolah 2018.

Berdasarkan tabel 2 dapat diketahui bahwa masing-masing indikator yang digunakan baik dalam variabel penelitian mempunyai nilai loading factor yang lebih besar dari 0,50. Hal ini berarti indikator-indikator yang digunakan dalam variabel penelitian ini layak atau valid digunakan sebagai pengumpul data. Reliabilitas menunjukkan sejauh mana alat ukur dapat diandalkan atau dapat dipercaya. Pada penelitian ini dalam menghitung reliabilitas menggunakan composite (contruct) reliability dengan cut off value adalah minimal 0,70 (Ghozali, 2005).

Tabel 3 Hasil Uji Reliabilitas

\begin{tabular}{|c|c|c|c|c|c|c|}
\hline No. & Variabel & Indikator & Loading & $\lambda^{\square}$ & $1-\lambda^{2}$ & CR \\
\hline \multirow{6}{*}{1} & \multirow{6}{*}{$\begin{array}{l}\text { Kompetensi SDM } \\
\left(\mathrm{X}_{1}\right)\end{array}$} & $\mathrm{X} 11$ & 0,864 & 0,746 & 0,254 & \multirow{6}{*}{0,892} \\
\hline & & $\mathrm{X} 12$ & 0,865 & 0,748 & 0,252 & \\
\hline & & $\mathrm{X} 13$ & 0,921 & 0,848 & 0,152 & \\
\hline & & $\mathrm{X} 14$ & 0,654 & 0,428 & 0,572 & \\
\hline & & $\mathrm{X} 15$ & 0,525 & 0,276 & 0,724 & \\
\hline & & X16 & 0,584 & 0,341 & 0,659 & \\
\hline
\end{tabular}




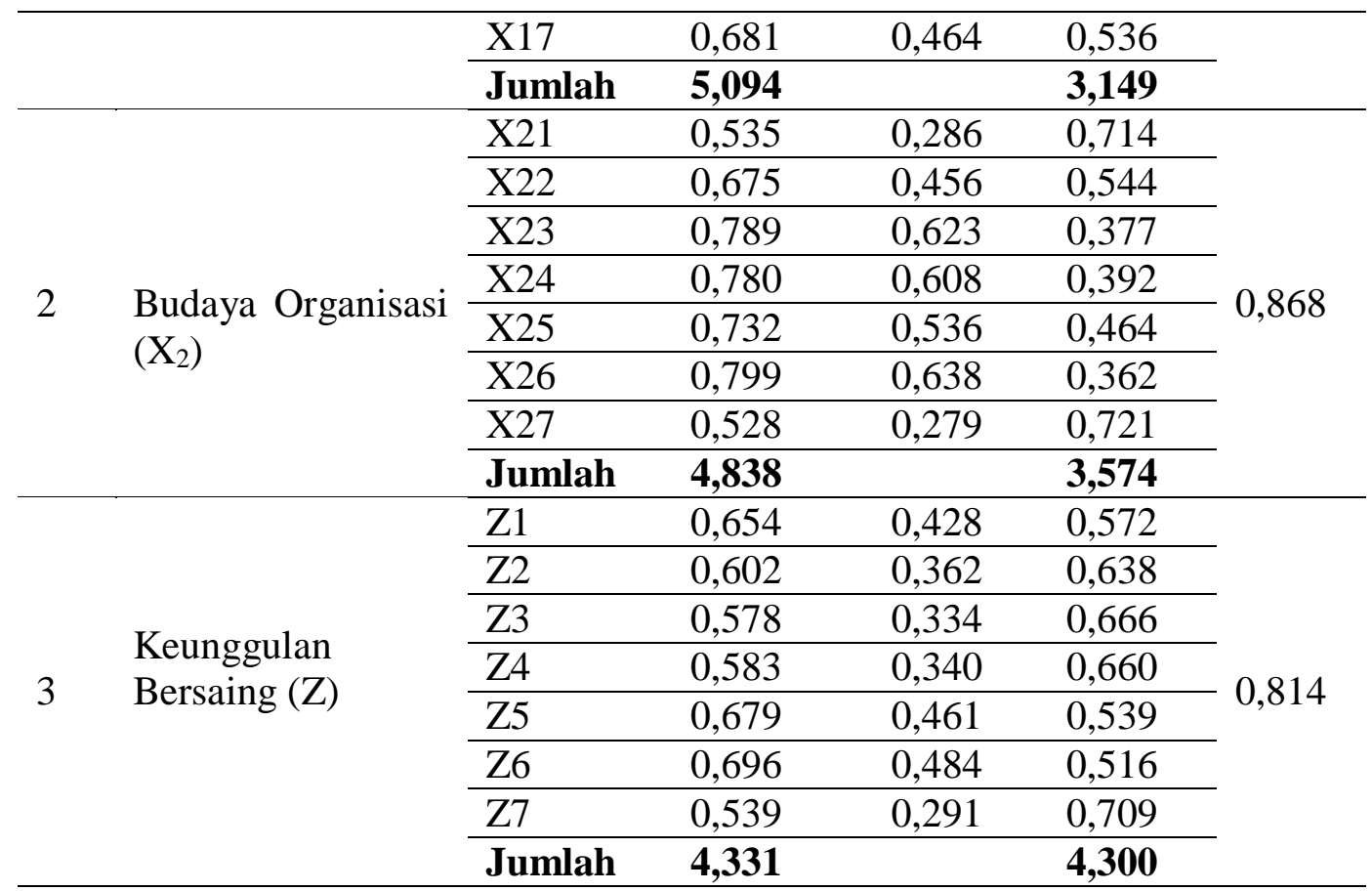

Sumber : Data Diolah 2018.

Berdasarkan tabel 3 dapat diketahui masing-masing variabel laten yang digunakan dalam penelitian memberikan nilai CR di atas nilai cut-off-nya sebesar 0,7. Sehingga dapat dikatakan masing-masing variabel laten reliabel.

\section{Uji Asumsi Structural Equation Modelling (SEM)}

Setelah dilakukan uji validitas dan reliabilitas pada masing-masing variabel laten, maka dilakukan uji asumsi untuk melihat apakah prasyarat yang diperlukan dalam permodelan SEM dapat terpenuhi. Prasyarat yang harus dipenuhi adalah asumsi multivariat normal, tidak adanya multikolinearitas atau singularitas dan outlier.

\section{Uji Normalitas}

Uji normalitas perlu dilakukan baik untuk normalitas terhadap data univariat maupun normalitas multivariat dimana beberapa variabel yang digunakan sekaligus dalam analisis akhir. Untuk menguji ada atau tidaknya asumsi normalitas, maka dapat dilakukan dengan dengan nilai statistik z untuk skewness dan kurtosisnya secara empirik dapat dilihat pada Critical Ratio (CR) yang digunakan tingkat signifikansi 5\%, maka nilai CR yang berada diantara $-2,58$ sampai dengan $2,58 \quad(-2,58 \leq \mathrm{CR} \leq 2,58)$ dikatakan data berdistribusi normal, baik secara univariat maupun secara multivariat (Ghozali, 2005). 
Hasil pengujian normalitas yang telah dilakukan diperoleh nilai CR sebesar 1,552 yang berarti $\mathrm{CR}$ yang berada diantara $-2,58$ sampai dengan 2,58. Sehingga dapat dinyatakan bahwa data multivariate normal. Selain itu juga data univariat normal ditunjukkan oleh semua nilai critical ratio semua indikator terletak diantara $-2,58 \leq \mathrm{CR} \leq$ 2,58

\section{Uji Multikolinearitas}

Multikolinearitas dapat dilihat melalui determinan matriks kovarians. Nilai determinan yang sangat kecil atau mendekati nol, menunjukkan indikasi terdapatnya masalah multikolinearitas atau singularitas, sehingga data tersebut tidak dapat digunakan untuk penelitian (Ghozali, 2005). Hasil pengujian multikolinieritas memberikan nilai determinant of sample covariance matrix sebesar 77,273. Nilai ini tersebut jauh di atas angka nol sehingga dapat disimpulkan bahwa tidak terdapat masalah multikolinieritas dan singularitas pada data yang dianalisis.

\section{Uji Outliers}

Outliers adalah observasi yang muncul dengan nilai ekstrim baik secara univariat maupun secara multivariat yaitu muncul karena kombinasi karakteristik unik yang dimiliki dan terlihat sangat jauh berbeda dari observasi-observasi lainnya. Apabila terjadi outliers dapat dilakukan perlakuan khusus pada outliers-nya asal diketahui bagaimana munculnya outliers tersebut. Deteksi terhadap multivariate outlier dilakukan dengan memperhatikan nilai Mahalanobis Distance. Kriteria yang digunakan adalah berdasarkan nilai Chi Square pada derajat kebebasan (degree of freedom) sebesar jumlah variabel indikator pada tingkat signifikansi $\mathrm{p}<0,01$ (Ghozali, 2005). Hasil uji outliers dalam penelitian ini menunjukkan besarnya nilai Mahalanobis $d$-squared lebih kecil dari nilai Chi Square pada $(27 ; 0,01)$ yaitu sebesar 46,963. Hal ini berarti dalam penelitian ini semua kasus tidak mengalami outliers atau dapat dikatakan tidak ada perbedaan yang signifikan antara data dengan kelompok data.

\section{Hasil Analisis Structural Equation Modelling (SEM)}

Pada tahap ini akan dibahas mengenai uji kesesuaian model dan uji signifikansi kausalitas. Hasil pengujian dengan program AMOS versi 16.0 memberikan hasil model SEM yang menunjukkan pengaruh kompetensi SDM dan budaya organisasi terhadap keunggulan bersaing pada UMKM di Jawa Timur. 
a. Uji Kesesuaian Model (Goodness of Fit Test)

Pengujian pada model SEM bertujuan untuk melihat kesesuaian model, hasil pengujian kesesuaian model dalam studi ini disajikan pada Tabel 6. berdasakan tabel tersebut dapat diketahui bahwa dari delapan kriteria yang digunakan untuk menilai layak/tidaknya suatu model, enam diantaranya telah terpenuhi. Sehingga dapat dinyatakan bahwa model dapat diterima yang berarti ada kesesuaian model dengan data.

\section{Tabel 4 Indeks Kesesuaian SEM}

\begin{tabular}{|c|c|c|c|}
\hline Kriteria & Nilai Cut Off & Hasil Pengujian & Keterangan \\
\hline Chi Square & $\begin{array}{ll}\text { Diharapkan } & \text { lebih } \\
\text { kecil dari } X^{2} & \text { pada } \\
\text { df }=294 & \text { yaitu } \\
341,395 & \end{array}$ & 318,272 & Baik \\
\hline Sig. Probability & $\geq 0,05$ & 0,158 & Baik \\
\hline RMSEA & $\leq 0,08$ & 0,027 & Baik \\
\hline GFI & $\geq 0,90$ & 0,863 & Marginal \\
\hline AGFI & $\geq 0,90$ & 0,823 & Marginal \\
\hline CMIN/DF & $\leq 2$ atau 3 & 1,083 & Baik \\
\hline TLI & $\geq 0,95$ & 0,984 & Baik \\
\hline CFI & $\geq 0,95$ & 0,987 & Baik \\
\hline
\end{tabular}

Sumber: Data Diolah 2018.

b. Uji Kausalitas

Setelah dilakukan pengujian kesesuian modal penelitian, maka langkah selanjutnya adalah menguji kausalitas yang dikembangkan dalam penelitian tersebut. Dari model yang sesuai, maka dapat diinterpretasikan masing-masing koefisien jalur. Pengujian koefisien jalur secara rinci disajikan dalam tabel 5.

Tabel 5 Hasil Uji Kausalitas

\begin{tabular}{lllrrll}
\hline \multicolumn{2}{l}{ Pengaruh } & Estimate & S.E. & C.R. & P & Label \\
\hline Z & $<---~ X 1$ & 0,246 & 0,086 & 2,845 & 0,004 & Signifikan \\
Z & <--- X2 & 0,539 & 0,160 & 3,375 & 0,000 & Signifikan \\
\hline
\end{tabular}

Sumber: Data Diolah 2018.

Berdasarkan tabel 5 dapat dinyatakan bahwa hasil pengujian koefisien jalur untuk pengaruh kompetensi SDM $\left(\mathrm{X}_{1}\right)$ terhadap keunggulan bersaing $(\mathrm{Z})$ memiliki jalur positif sebesar 0,246 dengan C.R sebesar 2,845 dan probabilitas (p) sebesar 0,004 yang berarti bahwa kompetensi SDM $\left(\mathrm{X}_{1}\right)$ berpengaruh signifikan terhadap keunggulan bersaing $(\mathrm{Z})$. Sehingga dapat dinyatakan bahwakKompetensi SDM berpengaruh terhadap keunggulan 
bersaing UMKM Makanan di Jawa Timur. Hal ini berarti jika kompetensi SDM semakin baik atau meningkat, maka akan meningkatkan keunggulan bersaing.

Hasil pengujian koefisien jalur untuk pengaruh budaya organisasi $\left(\mathrm{X}_{2}\right)$ terhadap keunggulan bersaing (Z) memiliki jalur positif sebesar 0,539 dengan C.R sebesar 3,375 dan probabilitas (p) sebesar 0,000 yang berarti bahwa budaya organisasi $\left(\mathrm{X}_{2}\right)$ berpengaruh signifikan terhadap keunggulan bersaing $(Z)$. Sehingga dapat dinyatakan bahwa budaya organisasi berpengaruh terhadap keunggulan bersaing UMKM makanan di Jawa Timur. Hal ini berarti jika budaya organisasi semakin baik, maka akan meningkatkan keunggulan bersaing.

\section{Pembahasan}

\section{Pengaruh Kompetensi SDM Terhadap Keunggulan Bersaing}

Hasil penelitian menunjukkan kompetensi SDM mempunyai pengaruh yang signifikan terhadap keunggulan bersaing UMKM Makanan di Jawa Timur. Hal ini berarti jika kompetensi SDM semakin baik atau meningkat, maka akan meningkatkan keunggulan bersaing. Teori berbasis sumberdaya menyatakan bahwa organisasi dapat menciptakan dan mempertahankan keunggulan kompetitifnya melalui proses penciptaan nilai yang langka dan sulit ditiru para kompetitor (Malayu, 2007). Indikasinya dapat dinilai dari kemampuan organisasi untuk mengkreasikan kebijakan dan praktik-praktik MSDM yang unik dan sulit ditiru pesaing. Hal ini akan mendorong terjadinya interaksi antar individu yang menghasilkan pengetahuan dan modal sosial serta menjadi pembeda organisasi atau perusahaan dengan pesaingnya yang kemudian mampu memberikan keuntungan ekonomis positif serta tidak mudah ditiru (Mathis dan Jackson, 2002). Adiputra dan Mandala (2017) menyatakan bahwa perusahaan yang mempunyai kompetensi SDM yang baik dapat meningkatkan keunggulan bersaing. Sahyar (2006) menyatakan bahwa kompetensi dosen dapat meningkatkan keunggulan perguruan tinggi. Kamidin (2010) berpendapat bahwa kompetensi dapat meningkatkan prestasi kerja pegawai sekretariat daerah Kabupaten Bantaeng.

\section{Pengaruh Budaya Organisasi Terhadap Keunggulan Bersaing}

Hasil penelitian menunjukkan budaya organisasi mempunyai pengaruh yang signifikan terhadap keunggulan bersaing UMKM Makanan di Jawa Timur. Hal ini berarti jika budaya organisasi semakin baik, maka akan meningkatkan keunggulan bersaing. Pabundu (2006) mengemukakan bahwa budaya organisasi merupakan sebuah sistem 
makna bersama yang dianut oleh para anggota yang membedakan suatu organisasi dari organisasi-organisasi lainnya. Budaya organisasi adalah sebuah pola asumsi dasar yang diciptakan, ditemukan atau dikembangkan oleh suatu kelompok tertentu sebagai landasan dalam berperilaku dalam organisasi. Dimana akan diturunkan kepada anggota baru sebagai cara bagaimana melihat, berpikir, dan merasa dalam organisasi. Tingginya tingkat persaingan antar organisasi membuat para pengambil keputusan perlu melakukan kajian yang mendalam tentang budaya organisasi atas 4 (empat) elemen yang saling berkaitan yaitu faktor manajerial, faktor lingkungan, kultur organisasi, perencanaan stratejik dan keunggulan bersaing. Budaya organisasi mencakup mengenai nilai, aturan, kepercayaan di dalamnya yang membentuk perilaku, sikap yang menguntungkan. Yuwalliatin (2006) dalam penelitiannnya mengatakan bahwa budaya organisasi dapat meningkatkan keunggulan bersaing. Lukito dan Devie (2015) dalam penelitiannya diketahui bahwa, budaya perusahaan berpengaruh secara signifikan terhadap keunggulan bersaing secara langsung.

\section{KESIMPULAN DAN SARAN}

\section{Kesimpulan}

Berdasarkan uraian-uraian yang telah diungkapkan pada pembahasan, maka dapat diambil beberapa kesimpulan sebagai jawaban atas pokok permasalahan yang diajukan dalam penelitian ini, yaitu:

1. Kompetensi SDM berpengaruh terhadap keunggulan bersaing UMKM Makanan di Jawa Timur.

2. Budaya Organisasi berpengaruh terhadap keunggulan bersaing UMKM Makanan di Jawa Timur.

\section{Saran}

Dari hasil penelitian ini kiranya peneliti dapat memberikan saran, diantaranya:

1. Hasil penelitian membuktikan bahwa kompetensi SDM dan budaya organisasi berpengaruh terhadap keunggulan bersaing. Oleh karena itu hendaknya UMKM Makanan di Jawa Timur selalu memperhatikan kompetensi SDM dan membangun dan menanamkan budaya organisasi yang kuat yang pada akhirnya mampu mendorong keuanggulan bersaing.

2. Bagi penelitian lanjutan disarankan untuk menambahkan variabel lain seperti profesionalisme, kreativitas dan inovasi, dan lain-lain. Sehingga dapat memperoleh 
hasil temuan yang lebih baik dalam menjelaskan kinerja organisasi dan berguna bagi pengembangan ilmu pengetahuan khususnya manajemen.

\section{DAFTAR PUSTAKA}

Adiputra, I Putu Pratama dan Kastawan Mandala. 2017. Pengaruh Kompetensi Dan Kapabilitas Terhadap Keunggulan Kompetitif Dan Kinerja Perusahaan. E-Jurnal Manajemen Unud, Vol. 6, No. 11, 6090-6119 ISSN : 2302-8912

Abadiyah, Rifdah. 2013." Analisis Pengaruh Perencanaan Stratejik Terhadap Kinerja Organisasi Dalam Upaya Menciptakan Keunggulan Bersaing Industri Kecil Menengah Tas Dan Koper Kecamatan Tanggulangin Kabupaten Sidoarjo". Prosiding Call for Paper. Fakultas Ekonomi Universitas Muhammadiyah Sidoarjo.

Assegaf dan Wasitowati, 2015. Knowledge Sharing Sebagai Sumber Inovasi dan Keunggulan Bersaing Pada Usaha Mikro Kecil dan Menengah (UMKM) Sektor Batik. CBAM. Unisula Semarang.

Azhad, M. Naely dan Anwar. 2016. Strategi Peningkatan Kinerja Dosen Berbasis OCB, Motivasi Spiritual Di Kabupaten Jember. Jurnal IOSR India.

Azhad, M. Naely dan Anwar, Nurul Qomariah. 2015. Manajemen Sumberdaya Manusia. CV. Cahaya Ilmu Jember.

Basuki dan Rahmi Widyanti, 2014. Pengaruh Strategi Keunggulan Bersaing Dan Orientasi Pasar Terhadap Kinerja Pemasaran Perusahaan. Jurnal Universitas Islam Kalimantan.

Dirgantoro, Crown. 2001. Manajemen Stratejik Konsep, Kasus, dan Implementasi.Grasindo, Jakarta.

Erwansyah, Memed, Sulastini, Hereyant. 2018. Pengaruh Kompetensi, Disiplin Kerja Dan Lingkungan Kerja Terhadap Kinerja Pegawai (Survey Pada PT. Bank Negara Indonesia (Persero) Tbk Kantor Cabang Muara Teweh Kabupaten Barito Utara). Jurnal Bisnis dan Pembangunan, Edisi Januari- Juni 2018 Vol 7, No. 1, ISSN 2541-187X

Ghozali, Imam. 2005. “Structural Equation Modeling. Metode Alternative Dengan Partial Least Squares. Semarang: Badan Penerbit Universitas Diponegoro.

Jahidi, Idi. 2013. "Persiapkan SDM Berbasis Kompetensi Global”. ASM Ariyanti.

Kamidin, M (2010), "Pengaruh kompetensi terhadap prestasi kerja pegawai sekretariat daerah Kabupaten Bantaeng,” Jurnal Economic Resources, Vol. 11, No. 30, pp. 79-91. 
Lukito, Angel Caroline dan Devie. 2015. Pengaruh Budaya Perusahaan Terhadap Keunggulan Bersaing Melalui Kepuasan Karyawan Pada Perusahaan Kafe Restoran Di Surabaya. Business Accounting Review, Vol. 3, No. 1, Januari 2015: 280-291.

Malayu S.P. Hasibuan, 2007, Manajemen Sumber Daya Manusia, (Ed Revisi 9), Jakarta : PT. Bumi Aksara.

Mathis Robert L dan Jackson John H. 2002. Human Resoursce Management, Alih Bahasa. Jakarta : Salemba Empat.

Pabundu, Tika, 2006, Budaya Organisasi dan Peningkatan Kinerja Perusahaan, Jakarta: Cetakan Pertama, PT Bumi Aksara.

Porter, M. E., 1993, Keunggulan Bersaing : Menciptakan dan Mempertahankan Kinerja Unggul, Erlangga, Jakarta.

Sahyar. 2006. Pengaruh Kompetensi Dosen Dan Proses Pembelajaran Terhadap Keunggulan Bersaing Program Studi Di Pendidikan Tinggi. EKUITAS. ISSN 1411-0393 Akreditasi No.55a/DIKTI/Kep/2006.

Winandi dan Budiono (2009), "Pengaruh iklim kerja, kompensasi dan kompetensi terhadap produktivitas kerja pegawai dan dosen pada STIE-STMIK Insan Pembangunan," JOCE IP, Vol. 3, No.1, pp. 64-74.

Yuwalliatin, Sitty. 2006. Pengaruh Budaya Organisasi, Motivasi dan Komitmen Terhadap Kinerja Serta Pengaruhnya Keunggulan Kompetitif Dosen Unisulla Semarang. Jurnal Ekobis. Vol. 7 No. 2

Http://Surabaya.Tribunnews.Com/2013/05/31/Jumlah-Umkm-Di-Jatim-Mencapai-68Juta. 